\title{
NOTE
}

\section{Deep occurrence of the giant kelp Macrocystis laevis in the Southern Ocean}

\author{
Renzo Perissinotto, Christopher D. McQuaid
}

Southern Ocean Group, Department of Zoology and Entomology, Rhodes University, PO Box 94, Grahamstown 6140, South Africa

\begin{abstract}
During a combined hydroacoustic-trawling survey at the Prince Edward Archipelago, a kelp bed of Macrocystis laevis growing at a maximum depth of $68 \mathrm{~m}$ was repeatedly observed in the open shelf area. This is the deepest population ever described for any species of giant kelp. Nutrient availability and temperature in the area were found to have no significant impact on kelp production and distribution. Likewise, measurements of photon flux density showed that neither plant growth nor sporophyte formation was likely to have been light-inhibited during the period of the observations. However, since irradiance levels in the deep kelp bed were close to the lower threshold for growth, the absence of plants below $68 \mathrm{~m}$ depth was probably determined by light availability. Around Marion Island, where M. laevis is found only within the $20 \mathrm{~m}$ isobath, the offshore limit of the kelp beds is controlled by availability of suitable rock substrata. The inshore limit appears to be set by the maximum height of storm-induced waves.
\end{abstract}

Four species of Macrocystis are generally recognized: $M$. integrifolia, $M$. angustifolia, $M$. pyrifera and the recently described $M$. laevis (Womersley 1954, Neushul 1971, Hay 1986, Brostoff 1988). Macrocystis kelps are found in cold temperate oceans with surface temperatures varying from 0 to $20^{\circ} \mathrm{C}$, and their main distribution is circumpolar in the Southern Hemisphere, between 40 and $60^{\circ} \mathrm{S}$ (Table 1; Cribb 1954, Michanek 1983). They are also present in the major coastal upwelling areas. On the west coast of South Africa they occur between $33^{\circ} 24^{\prime}$ and $34^{\circ} 8^{\prime} \mathrm{S}$ and on the Pacific coast of South America extend almost to the equator, reappearing in North America along Baja California and reaching southern Alaska to the north (Table 1).

Only 2 species of Macrocystis are represented in the Southern Ocean: $M$. pyrifera and $M$. laevis. While $M$. pyrifera is widely distributed from subantarctic South America to New Zealand, and occurs at most islands in the Atlantic and Indian sectors of the Southern Ocean, $M$. laevis is endemic to the Prince Edward Archipelago (Hay 1986).

Along rocky coasts, the inshore limit of Macrocystis forests is usually controlled by wave action and tidal ranges (North 1971, Seymour et al. 1989). The offshore limit appears to be determined by different factors for the various species. $M$. integrifolia and $M$. angustifolia are restricted to shallow intertidal and subtidal areas (Table 1) and their lower depth limits are set by sea urchin grazing and wave action, respectively (Papenfuss 1942, Druehl 1978). $M$. pyrifera and $M$. laevis extend to deeper subtidal depths and further offshore (Table 1). Their lower limits seem to be primarily controlled by light intensity at the bottom (Neushul \& Haxo 1963, Peres 1982, Dean \& Jacobsen 1984). M. pyrifera beds in turbid waters usually do not extend below 10 to $20 \mathrm{~m}$, but in clearer offshore waters they may reach 30 to $40 \mathrm{~m}$ (Grua 1964, North 1971).

The deepest occurrence of Macrocystis pyrifera was recorded at $54.9 \mathrm{~m}$ in southern Argentina by Neushul (1971), who described this finding as 'enigmatic'. Similarly, Hay (1986) expressed scepticism about the earliest record of $M$. laevis at Marion Island, supposedly collected from a depth of 40 fathoms, ca $73 \mathrm{~m}$ (Dickie 1877). Here, we provide evidence that $M$. laevis in the Prince Edward Archipelago can occur down to a depth of at least 60 to $65 \mathrm{~m}$.

Observations on the depth distribution of Macrocystis laevis were made from the SA 'Agulhas' in April/ May and August 1989. On both occasions, acoustic records were taken along 2 transects crossing the islands' shelf with $12 \mathrm{kHz}$ NEC NS-74 and $120 \mathrm{kHz}$ SIMRAD EKS echo-sounders. Samples of kelp were collected in April 1989 using an opening-closing RMT2 net towed at 2.5 to 3.0 knots. Haul depth was controlled by a Universal Underwater Unit (Robertson et al. 1981).

Conductivity, temperature and depth (CTD) casts in the area were made using a Neil Brown MK III probe. At selected depths $(0,10,20,50$ and $100 \mathrm{~m})$, the concentrations of nitrogenous nutrients (nitrate, nitrite, ammonia and urea) were measured with a Technicon 
Macrocystis spp. Geographic distribution and maximum depth of occurrence

\begin{tabular}{|c|c|c|c|}
\hline Species & Distribution & Depth $(m)$ & Source \\
\hline M. angustifolia & $\begin{array}{l}\text { South Africa } \\
\text { South Australia }\end{array}$ & $\begin{array}{l}8 \\
6\end{array}$ & $\begin{array}{l}\text { Isaac }(1937) \\
\text { Womersley }(1954)\end{array}$ \\
\hline M. integrifolia & $\begin{array}{l}\text { British Columbia } \\
\text { US Pacific coast } \\
\text { Chile } \\
\text { Peru }\end{array}$ & $\begin{array}{r}10 \\
9 \\
8 \\
20\end{array}$ & $\begin{array}{l}\text { Druehl (1978) } \\
\text { Michanek (1983) } \\
\text { Neushul (1971) } \\
\text { Juhl-Noodt (1958) }\end{array}$ \\
\hline M. pyrifera & $\begin{array}{l}\text { Southern California } \\
\text { Baja California } \\
\text { Southern Chile } \\
\text { Peru } \\
\text { Southern Argentina } \\
\text { Tasmania } \\
\text { New Zealand } \\
\text { Kerguelen Is. } \\
\text { Crozet Is. } \\
\text { St. Paul-Amsterdam Is. } \\
\text { Falkland Is. } \\
\text { South Georgia Is. } \\
\text { Gough-Tristan Is. }\end{array}$ & $\begin{array}{l}30 \\
40 \\
10 \\
40 \\
55 \\
30 \\
16 \\
40 \\
25 \\
20 \\
25 \\
25 \\
30\end{array}$ & $\begin{array}{l}\text { Neushul \& Haxo (1963) } \\
\text { North (1971) } \\
\text { Dayton et al. (1973) } \\
\text { Juhl-Noodt (1958) } \\
\text { Neushul (1971) } \\
\text { Michanek (1983) } \\
\text { Hay (1990) } \\
\text { Grua (1964) } \\
\text { Delépine (1966) } \\
\text { Delépine (1966) } \\
\text { Powell (1981) } \\
\text { Skottsberg (1941) } \\
\text { Baardseth (1941) }\end{array}$ \\
\hline M. laevis & Prince Edward Is. & 73 & Dickie (1877) \\
\hline
\end{tabular}

Autoanalyzer II system (Strickland \& Parsons 1968, Mostert 1983). In April/May 1989, 16 depth profiles of photosynthetically available radiation (PAR) were obtained in the shelf and circuminsular waters of the archipelago using a Biospherical Instruments irradiance meter (model QSP 170B). Surface irradiance levels were measured at regular intervals of 2 to $4 \mathrm{~h}$ throughout the survey.

Macrocystis laevis in the Prince Edward Archipelago is abundant along the east coast of Marion Island, with a few isolated patches on the exposed west and southern shores (Fig. 1; Attwood et al. 1991). These kelp beds cover a total area of ca $5.5 \mathrm{~km}^{2}$ and extend more than $100 \mathrm{~m}$ offshore, at depths between $5-10$ and $20 \mathrm{~m}$ (De Villiers 1976, Attwood et al. 1991, Beckley \& Branch in press). They all form dense canopies at the surface.

Well-developed beds of Macrocystis laevis were observed during both autumn and winter surveys (April/May and August 1989) on Natal Bank, an isolated prominence shoaling to $45 \mathrm{~m}$ below sea level and located on the shelf between Marion and Prince Edward Islands (Fig. 1). Kelp was recorded on both the 12 and $120 \mathrm{kHz}$ echograms and extended upward towards the surface from a maximum bottom depth of ca $68 \mathrm{~m}$ (Figs. $2 \& 3$ ). They were never observed to form canopies at the surface and, according to the echograms, the longest stipes reached a length of 20 to 25 $\mathrm{m}$. This indicates that the apical portions of the plants were $>30 \mathrm{~m}$ below the sea surface. On 26 April fronds were collected while towing the RMT- 2 net at between 52 and $67 \mathrm{~m}$.

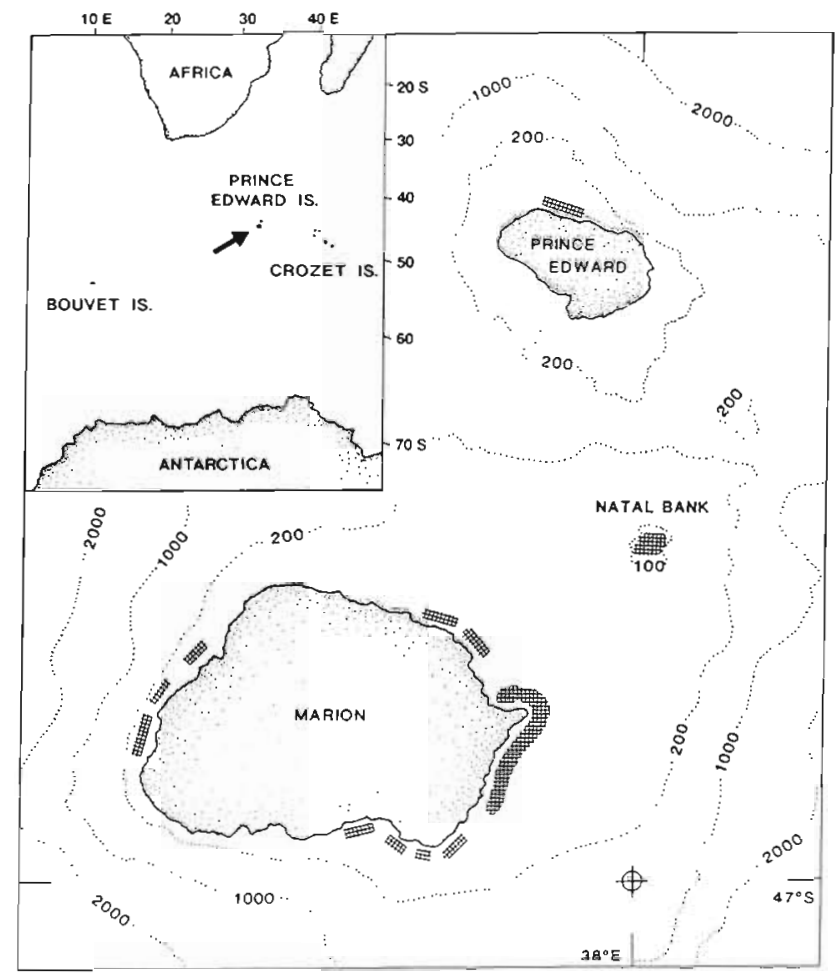

Fig. 1. Bottom topography (depth contours in metres) and distribution (shaded areas) of Macrocystis laevis around the Prince Edward Islands

An estimation, based on echograms, of kelp cover within the $60 \mathrm{~m}$ isobath on Natal Bank gives values of about 53 and $46 \%$ of the total area in April and August, respectively (Fig. 3). An area of about $2.5 \mathrm{~km}^{2}$ lies 
Fig. 2. $120 \mathrm{kHz}$ acoustic records along a transect crossing the Natal Bank. (A) 26 April 1989; (B) 23 August 1989. Arrows indicate deep kelp beds of Macrocystis laevis
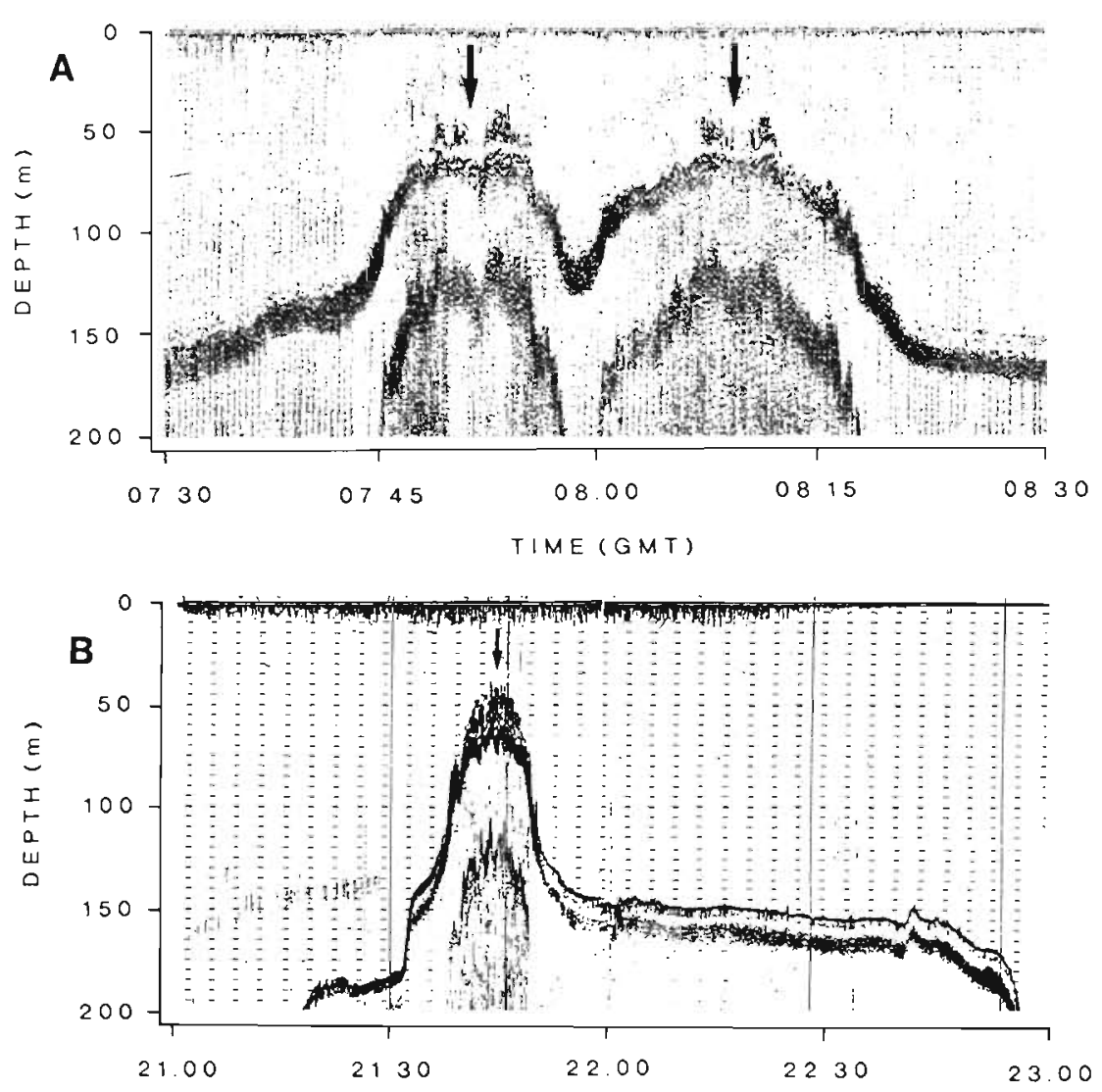

TIME (GMT)

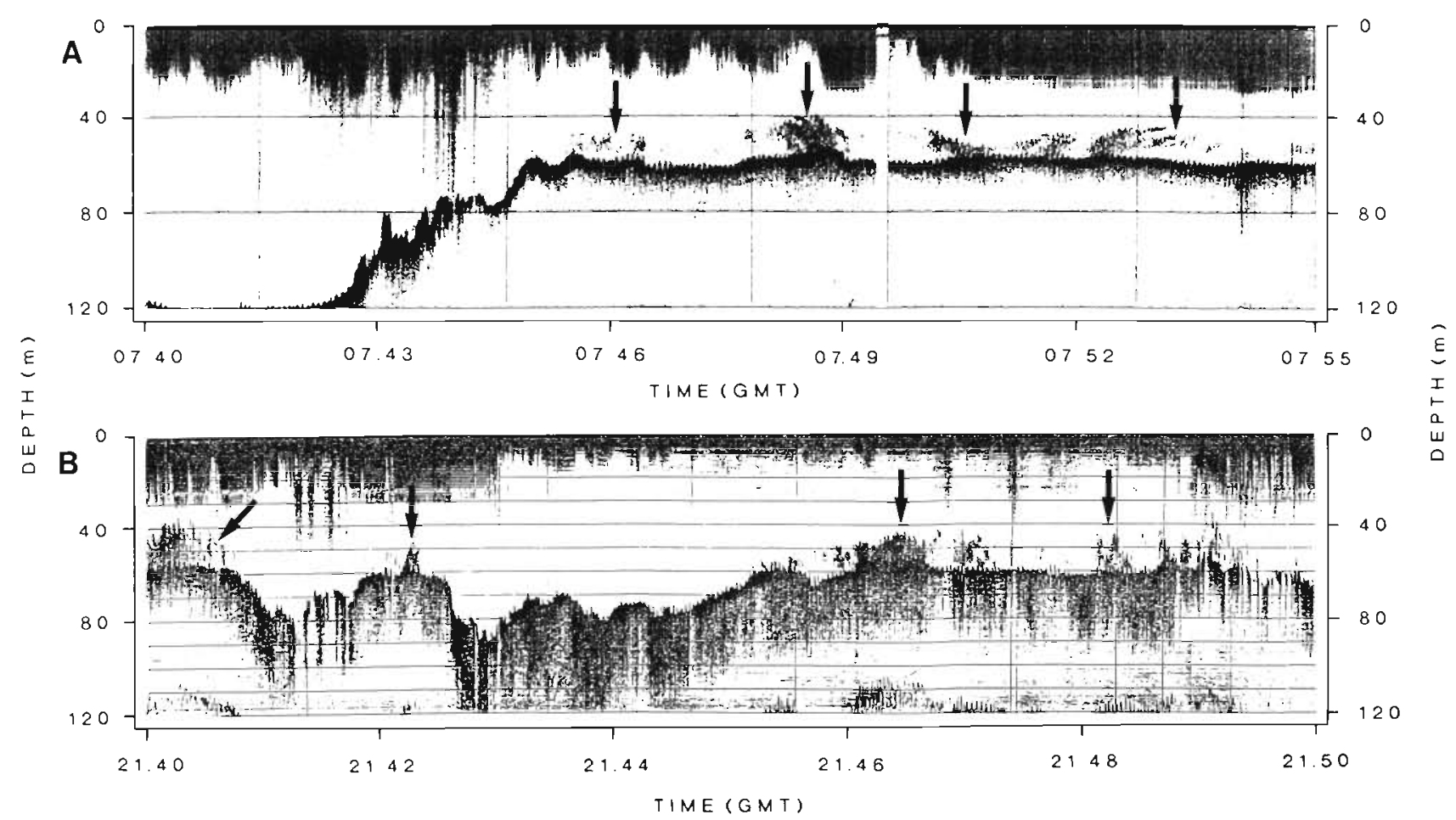

Fig. 3. $12 \mathrm{kHz}$ acoustic records along a transect crossing the Natal Bank. (A) 26 April 1989; (B) 23 August 1989. Arrows indicate deep kelp beds of Macrocystis laevis 
within the $60 \mathrm{~m}$ isobath, indicating a kelp forest of 1.0 to $1.3 \mathrm{~km}^{2}$, i.e. about one-fifth of the population found around Marion Island. Assuming plant weights and densities similar to those of the coastal population (i.e. 0.875 holdfasts $\mathrm{m}^{-2}$ and $13.21 \mathrm{~kg} \mathrm{plant}^{-1}$; Attwood et al. 1991), the total biomass of Macrocystis laevis on Natal Bank could amount to ca 1.1 to $1.5 \times 10^{4} \mathrm{t}$ (wet $w t$ ), or ca 700 to 900 t (carbon).

To our knowledge, the population of Macrocystis laevis in the Prince Edward Archipelago is the deepest ever described for any species of giant kelp. There are 2 previous records of $M$. laevis at great depths. During the 'Challenger' expedition the kelp was hauled from 40 fathoms ( 1 fathom $=1.83 \mathrm{~m}$; Dickie 1877), and in March 1976 it was dredged at 58 m on Natal Bank by the 'Marion-Dufresne' (Arnaud \& Hureau 1979).

The most important factors controlling Macrocystis production and distribution are nitrogen availability (Jackson 1977, Wheeler \& North 1981, Gerard 1982), temperature (North 1971, Dean \& Jacobsen 1984, Hay 1990), nature of the substratum (Cribb 1954, North 1971, Druehl 1978, Peres 1982), herbivore grazing (Leighton 1971, Druehl 1978, Dean et al. 1984), irradiance (Neushul \& Haxo 1963, Neushul 1971, Dean \& Jacobsen 1984, Reed \& Foster 1984, Deysher \& Dean 1986) and wave action (ZoBell 1971, Dayton et al. 1984, Seymour et al. 1989). Most of these act synergistically and their relative importance is often variable, depending on season and location (North 1971, Druehl 1978, Dean \& Jacobsen 1984, Hay 1990).

Most studies on the physiological and ecological requirements of Macrocystis have been carried out on the widely distributed $M$. pyrifera. Until its recent description as a separate species, $M$. laevis has been confused with this congeneric kelp (De Villiers 1976. Hay 1986, Attwood et al. 1991). Both species (mutually exclusive) occur in the subantarctic zone of the Southern Ocean, and are biogeographically linked by the Antarctic Circumpolar Current. It seems reasonable, therefore, to assume that their physiology and ecology are very similar (Attwood et al. 1991).

Analysis of environmental control of seaweed growth and distribution requires a combination of in situ and laboratory measurements of all the parameters involved, taking into account daily, monthly and seasonal variations. Admittedly, the data set available for the Prince Edward Island seas still lacks this comprehensiveness. Nevertheless, data on many environmental variables have been collected over the past decade with sufficient regularity to allow the elaboration of some preliminary results and hypotheses.

Ambient nitrate $\left(\mathrm{NO}_{3}\right)$ concentrations in the area (13 to 26 umol $\mathrm{N} \mathrm{I}^{-1}$. Fig. 4; Duncombe Rae 1989, Van Ballegooyen et al. 1989, Perissinotto et al. 1990) are well above growth-limiting levels for Macrocystis of

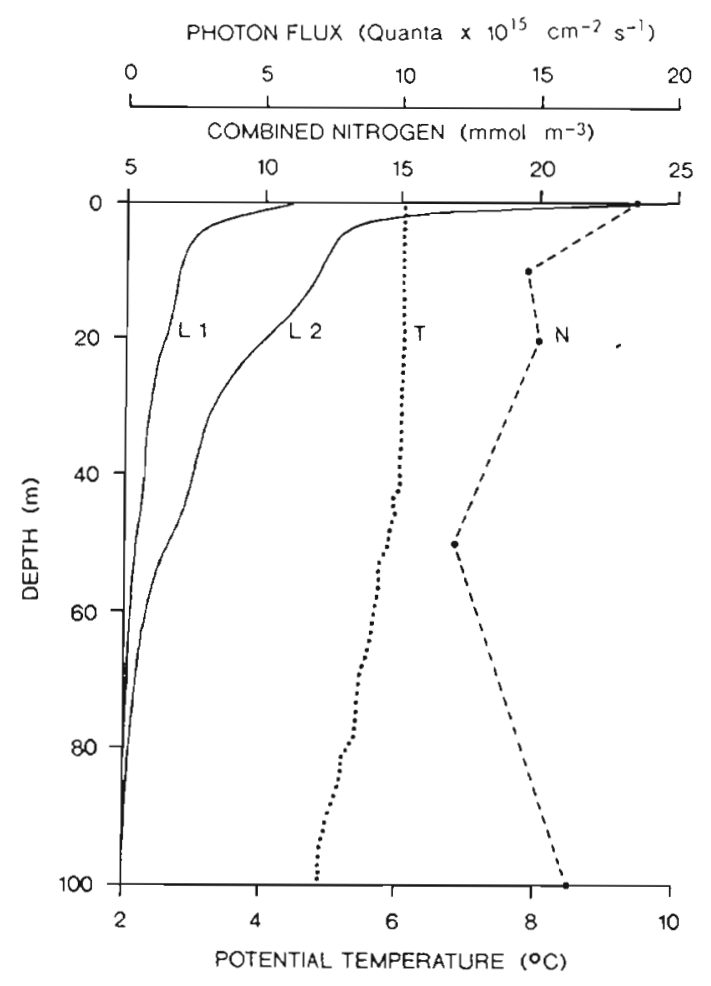

Fig. 4. Selected vertical profiles of temperature ( $T$, dotted line), combined nitrogenous nutrients ( $N$, dashed line) and light intensity (continuous lines) representative of the physicochemical environment on Natal Bank during April 1989. L1 and $\mathrm{L} 2$ represent light profiles under the heaviest and lightest overcast conditions, respectively

$<1$ umol N $1^{-1}$ (Jackson 1977, Gerard 1982, Dean \& Jacobsen 1984), and tissue nitrogen content (2.1 to $2.9 \%$ of dry weight; Attwood et al. 1991) far exceeds levels for nitrogen-deficient Macrocystis $(0.7$ to $1.1 \%$; Gerard 1982). Maximum and minimum temperatures (8.0 and $2.1^{\circ} \mathrm{C}$, respectively; Schulze 1971) also lie within the optimal range of 0 to $18^{\circ} \mathrm{C}$ for Macrocystis growth (Cribb 1954, Womersley 1954, Michanek 1983).

Data on the diet of the local herbivore community are still too limited to permit conclusions on grazing effects on Macrocystis laevis. However, the 2 most abundant grazers (the sea urchin Pseudochinus marionus and the isopod Dynamenella huttoni) appear to feed primarily on kelp detritus rather than living plants (Attwood et al. 1991).

The effect of underwater irradiance on depth limitation deserves particular attention. Light availability may be limiting, as predominantly overcast conditions at the archipelago reduce the annual sunshine duration to $<30 \%$ of the maximum possible, and yearly average photon flux density (ca $40 \mathrm{~mol} \mathrm{~m}^{-2} \mathrm{~d}^{-1}$ ) is less than $30 \%$ of the estimated world average (Schulze 1971, Smith 1987). In the absence of nutrient and temperature limitations, Macrocystis requires a minimum 
photon flux of ca 0.24 to $0.42 \mathrm{~mol} \mathrm{~m}^{-2} \mathrm{~d}^{-1}$ for growth (Neushul \& Haxo 1963, Clendenning 1971, Dean \& Jacobsen 1984) and ca 0.20 to $0.25 \mathrm{~mol} \mathrm{~m}^{-2} \mathrm{~d}^{-1}$ for sporophyte production by gametophytes (Deysher \& Dean 1984, 1986).

In April/May 1989, surface irradiation around the Prince Edward Archipelago ranged from 5.8 to $115 \mathrm{~mol}$ $\mathrm{m}^{-2} \mathrm{~d}^{-1}$, depending on cloud cover, and averaged 39.8 mol m $\mathrm{m}^{-2} \mathrm{~d}^{-1}$. The water column in the immediate vicinity of the deep kelp bed at Natal Bank was very clear at the time of the survey (Fig. 4). The extinction coefficient was remarkably low $\left(0.059\right.$ to $\left.0.054 \mathrm{~m}^{-1}\right)$, while the euphotic zone reached 78 to $85 \mathrm{~m}$. In the absence of canopy shading, the deepest depths at which Macrocystis laevis was attached (ca $68 \mathrm{~m}$ ) received a photon flux of ca 0.29 to $0.43 \mathrm{~mol} \mathrm{~m} \mathrm{~m}^{-2} \mathrm{~d}^{-1}$, i.e. just above the thresholds for both growth and sporophyte formation. Recruitment of young plants on the bank is possible under these conditions, but below $68 \mathrm{~m}$ depth their growth is probably inhibited by insufficient light.

Irradiance levels at the depth of the upper extent of their stipes in the water column (ca 35 to $40 \mathrm{~m}$ ) ranged between 1.2 and $2.0 \mathrm{~mol} \mathrm{~m} \mathrm{~m}^{-2} \mathrm{~d}^{-1}$. These values fall within, or close to, the light saturation range for Macrocystis growth of 1.8 to $3.0 \mathrm{~mol} \mathrm{~m}^{-2} \mathrm{~d}^{-1}$ (Neushul \& Haxo 1963, Dean \& Jacobsen 1984). Although shortening of the photoperiod during winter must affect growth rates, acoustic records taken over the Natal Bank (Figs. 2 \& 3) show no obvious difference in kelp bed cover between autumn (April/May) and winter (August).

The shelf area of the archipelago exhibits an island mass effect which results in the periodic formation of dense phytoplankton blooms (Allanson et al. 1985, Boden 1988, Perissinotto \& Duncombe Rae 1990, Perissinotto et al. 1990). Phytoplankton cells can dramatically reduce the light penetration by absorption and scattering and may cause periodical inhibition in the growth of the deepest kelp beds (Clendenning 1971).

In contrast to its deep occurrence on Natal Bank, around Marion Island Macrocystis laevis is usually restricted to a depth of ca $20 \mathrm{~m}$. This limit probably reflects the availability of suitable substrata. Macrocystis requires a hard substratum for attachment and even when solidly anchored, burial of the holdfast by sand or mud may cause the removal of entire kelp beds (Cribb 1954, North 1971, Reed \& Foster 1984, Schiel \& Foster 1986). Turbulence near the bottom may also resuspend fine sediment in the water column, reducing the photon flux below the sea surface (Foster 1975, Schiel \& Foster 1986).

The shelf area is extensively covered with sediments, from fine mud to small cobbles, which extend inshore to at least the $25 \mathrm{~m}$ isobath (Arnaud \& Hureau 1979). Macrocystis laevis is densest in shallower waters where lava platforms and boulders ( 1 to $3 \mathrm{~m}$ diameter; De Villiers 1976) form the substratum, but extends much deeper where rock surfaces emerge from the sediments, for example Natal Bank and on the east coast of Marion Island, where kelp has been collected at $50 \mathrm{~m}$ (Arnaud \& Hureau 1979).

Finally, differences in distribution and abundance between the eastern and the other shores of Marion Island can be explained by wave exposure. The climate of the archipelago is dominated by northwesterly winds which reach gale force (>55 $\mathrm{km} \mathrm{h}^{-1}$ ) on average on 107 days per year (Schulze 1971. Smith 1987). This generates swells up to $20 \mathrm{~m}$ high on the west shore, while the eastern or lee shore has a maximum wave height of only ca $4 \mathrm{~m}$ (De Villiers 1976, Lutjeharms 1990). Waves break when the ratio of wave height to water depth is about 0.8 (Knauss 1978) and can cause severe damage to Macrocystis (Seymour et al. 1989). This may explain why $M$. laevis beds can extend inshore to the $5 \mathrm{~m}$ isobath on the eastern shore (Attwood et al. 1991), but occur only further offshore on the south and northwest coasts (De Villiers 1976).

Acknowledgements. We thank A. A. Robertson of the Sea Fisheries Research Institute, Cape Town, for providing equipment and technical assistance for the survey. Funding from the Department of Environment Affairs through the South African Committee for Antarctic Research (SACAR) is gratefully acknowledged

\section{LITERATURE CITED}

Allanson, B. R., Boden, B. P., Parker, L. D., Duncombe Rae, C. M. (1985). A contribution to the oceanology of the Prince Edward Islands. In: Siegfried, W. R., Condy, P. R., Laws, R. M. (eds.) Antarctic nutrient cycles and food webs. Springer, Berlin, p. 38-45

Arnaud, P. M., Hureau, J. C. (1979). Compte-rendı de la campagne MD.08/Benthos (7 mars-26 avril 1976): liste des stations et donneés scientifiques générales. Com. natn. Fr Rech. Antarct. Publ. 44: 1-37

Attwood, C. G., Lucas, M. I., Probyn, T A., McQuaid, C. D. Fielding, P. J. (1991). Production and standing stocks of the kelp Macrocystis laevis Hay at the Prince Edward Islands, Subantarctic. Polar Biol. 11. 129-133

Baardseth, E. (1941). The marine algae of Tristan da Cunha. Res. Norw. scient. Exped. Tristan da Cunha 1937-1938 9: $1-174$

Beckley, L. E., Branch, G. M. (in press). A quantitative scubadiving survey of the sublittoral macrobenthos at subantarctic Marion Island. Polar Biol.

Boden, B. P. (1988). Observations of the island mass effect in the Prince Edward Archipelago. Polar Biol. 9: 61-68

Brostoff, W. N. (1988). Taxonomic studies of Macrocystis pyrifera (L.) C. Agardh (Phaeophyta) in southern California: holdfasts and basal stipes. Aquat. Bot. 31: 289-305

Clendenning, K. A. (1971). Photosynthesis and general development in Macrocystis. Beih. Nova Hedwigia 32: 169-190

Cribb, A. B. (1954). Macrocystis pyrifera (L.) Ag. in Tasmanian waters. Aust. I. mar Freshwat. Res. 5: 1-34 
Dayton, P. K., Currie, V., Gerrodette, T., Keller, B., Rosenthal, R., Tresca, D. V. (1984). Patch dynamics and stability of southern California kelp communities. Ecol. Monogr. 54: 253-289

Dayton, P. K., Rosenthal, R. J, Mahan, L. C. (1973). Kelp communities in the Chilean Archipelago: R/V Hero cruise, 1972-1975. Antarctic J. U.S. 8: 34-35

Dean, T. A., Jacobsen, F. R. (1984). Growth of juvenile Macrocystis pyrifera (Laminariales) in relation to environmental factors. Mar. Biol. 83: 301-311

Dean, T A., Schroeter, S. C., Dixon, J. D. (1984). Effects of grazing by two species of sea urchins (Strongylocentrotus franciscanus and Lytechinus anamesus) on recruitment and survival of two species of kelp (Macrocystis pyrifera and Pterigophora californica). Mar. Biol. 78: 301-313

Delépine, R. (1966). La végétation marine dans l'Antarctique de l'Ouest comparée à celle des lles Australes Francaises: conséquences biogéographiques. C. r. Soc. Biogéogr. 374 : $52-68$

De Villiers, A. F. (1976). Littoral ecology of Marion and Prince Edward Islands (Southern Ocean). S. Afr. J. antarct. Res. (Suppl.) 1: 1-40

Deysher, L. E., Dean, T. A. (1984). Critical irradiance levels and the interactive effects of quantum irradiance and dose on gametogenesis in the giant kelp, Macrocystis pyrifera. J. Phycol. 20: 520-524

Deysher, L. E., Dean, T. A. (1986). Interactive effects of light and temperature on sporophyte production in the giant kelp Macrocystis pyrifera. Mar. Biol. 93: 17-20

Dickie, G. (1877). Algae collected by Mr. Moseley at Marion Island, in 40 fathoms. Bot. J. Linn. Soc. 15: 42-43

Druehl, L. D. (1978). The distribution of Macrocystis integrifolia in British Columbia as related to environmental parameters. Can. J. Bot. 56: 69-79

Duncombe Rae, C. M. (1989). Data report of the first cruise of the Marion Off-shore Ecological Study (MOES-I). S. Afr natn. Sci. Prog. Rep. 159. Council for Scientific and Industrial Research, Pretoria, p. 1-384

Foster, M. S. (1975). Algal succession in a Macrocystis pyrifera forest. Mar. Biol. 32: 313-329

Gerard, V. A. (1982). Growth and utilization of internal nitrogen reserves by the giant kelp Macrocystis pyrifera in a low-nitrogen environment. Mar. Biol. 66: 27-35

Grua, P. (1964). Sur la structure des peuplements de Macrocystis pyrifera (L.) C. Ag. observés en plongée à Kerguelen et Crozet. C. r. hebd. Séanc. Acad. Sci., Paris 259 $1541-1543$

Hay, C. H. (1986). A new species of Macrocystis C. Ag (Phaeophyta) from Marion Island, southern Indian Ocean Phycologia 25: 241-252

Hay, C. H. (1990). The distribution of Macrocystis (Phaeophyta: Laminariales) as a biological indicator of cool sea surface temperature, with special reference to New Zealand waters. J. R. Soc. N.Z. 20:313-336

Isaac, W. E. (1937). Studies of South African seaweed vegetation. I. West coast from Lamberts Bay to the Cape of Good Hope. Trans. R. Soc. S. Afr. 25: 115-151

Jackson, G. A. (1977). Nutrients and production of giant kelp Macrocystis pyrifera, off southern California. Limnol. Oceanogr 22: 979-995

Juhl-Noodt, H. (1958). Beiträge zur Kenntnis der peruanischen Meeresalgen. I. Kieler Meeresforsch. 14: 167-174

Knauss, J. A. (1978). Introduction to physical oceanography. Prentice-Hall, Englewood Cliffs

Leighton, D. L. (1971). Grazing activities of benthic invertebrates in kelp beds. Beih. Nova Hedwigia 32: 421-453

Lutjeharms, J. R. E. (1990). The oceanography and fish dis- tribution of the Southern Ocean. In: Gon, O., Heemstra, P.C. (eds.) Fishes of the Southern Ocean. J.L.B. Smith Inst. Ichthyology, Grahamstown, p. 6-27

Michanek, G. (1983). World resources of marine plants. In Kinne, O. (ed.) Marine ecology, Vol. V, Ocean Management, Part 2. Wiley, New York, p. 795-837

Mostert, S. A. (1983). Procedures used in South Africa for the automatic photometric determination of micronutrients in seawater. S. Afr. J. mar. Sci. 1: 189-198

Neushul, M. (1971). The species of Macrocystis with particular reference to those of North and South America. Beih. Nova Hedwigia 32: 211-222

Neushul, M., Haxo, F. T. (1963). Studies on the giant kelp, Macrocystis. I. Growth of young plants. Am. J. Bot. 50 349-353

North, W. J. (1971). The biology of giant kelp beds (Macrocystis) in California: introduction and background. Beih. Nova Hedwigia 32: 1-97

Papenfuss, G. F. (1942). Studies of South African Phaeophyceae. I. EckJonia maxima, Laminaria pallida, Macrocystis pyrifera. Am. J. Bot. 29: 20-24

Peres, J. M. (1982). Major benthic assemblages. In: Kinne, $O$ (ed.) Marine ecology, Vol. V, Ocean Management, Part 1. Wiley, New York, p. 373-522

Perissinotto, R., Duncombe Rae, C. M. (1990). Occurrence of anticyclonic eddies on the Prince Edward Plateau (Southern Ocean): effects on phytoplankton biomass and production. Deep Sea Res. 37: 777-793

Perissinotto, R., Duncombe Rae, C. M., Boden, B. P., Allanson B. R. (1990). Vertical stability as a controlling factor of the marine phytoplankton production at the Prince Edward Archipelago (Southern Ocean). Mar. Ecol. Prog. Ser. 60: 205-209

Powell, H. T (1981). The ecology of Macrocystis and other kelps around the Falkland Islands (South Atlantic). In: Fogg, G. E., Jones, W. E. (eds.) Proc. 8th Int. Seaweed Symp. (Bangor, 1974). Marine Science Lab., Menai Bridge, p. $A 48$

Reed, D. C., Foster, M. S. (1984). The effects of canopy shading on algal recruitment and growth in a giant kelp forest. Ecology 65: 937-948

Robertson, A. A., Alexander, D. G. W., Miller, D. G. M. (1981). Modified collapsible opening and closing midwater trawls (RMT-8 and RMT-2). Fish. Bull. S. Afr. 14: 103-113

Schiel, D. R., Foster, M. S. (1986). The structure of subtidal algal stands in temperate waters. Oceanogr, mar. Biol. A. Rev. 24: 265-307

Schulze, B. R. (1971). The climate of Marion Island. In: Van Zinderen Bakker, E. M., Winterbottom, J. M., Dyer, R. A. (eds.) Marion and Prince Edward Islands: report on the South African biological and geological expedition, 1965-1966, Balkema, Cape Town, p. 16-31

Seymour, R. J., Tegner, M. J., Dayton, P. K., Parnell, P. E. (1989). Storm wave induced mortality of giant kelp, Macrocystis pyrifera, in southern California. Estuar coast. Shelf Sci. 28: 277-292

Skottsberg, C. (1941). Communities of marine algae in subantarctic and Antarctic waters. K. svenska VetenskAkad. Handl. 19: 1-95

Smith, V. R. (1987). The environment and biota of Marion Island. S. A.fr. J. Sci. 83: 211-220

Strickland, J. D. H., Parsons, T R. (1968). A practical handbook of seawater analysis. Bull. Fish. Res. Bd Can. 167: $1-311$

Van Ballegooyen, R., Perissinotto, R., Ismail, H., Boden, B., Allanson, B., Lucas, M., Lutjeharms, J. R. E. (1989). Data report of the second cruise of the Marion Off-shore Ecolog- 
ical Study (MOES-II). CSIR Rep. EMA-D 8910. Council for Scientific and Industrial Research, Stellenbosch, p. 1-402 Wheeler, P. A., North, W. J. (1981). Nitrogen supply, tissue composition and frond growth rates for Macrocystis pyrifera of the coast of southern California. Mar. Biol. 64: 59-69

This article was submitted to the editor
Womersley, H. B. S. (1954). The species of Macrocystis with special reference to those on southern Australian coasts. Univ. Calif. Publ. Bot. 27: 109-132

ZoBell, C. E. (1971). Drift seaweeds on San Diego county beaches. Beih. Nova Hedwigia 32: 269-314

Manuscript first received: August 20, 1991

Revised version accepted: February 12, 1992 